\title{
The Relation Between Task Value, Test Anxiety and Academic Self- Efficacy: A Moderation Analysis in High School Geography Course
}

\author{
Cennet Şanli* \\ Geography Department, Pamukkale University, Denizli, Turkey
}

ORCID: 0000-0003-3285-0950

\begin{tabular}{|c|c|}
\hline Article history & Areas where people utilize exams increase day by day. Learners \\
\hline $\begin{array}{l}\text { Received: } \\
22.06 .2020\end{array}$ & $\begin{array}{l}\text { intensively make an effort to achieve high scores and this process } \\
\text { causes them to experience high levels of stress and pressure. The }\end{array}$ \\
\hline $\begin{array}{l}\text { Received in revised form: } \\
11.08 .2020\end{array}$ & $\begin{array}{l}\text { present study explored the moderating effect of self-efficacy } \\
\text { beliefs in the relationship between task value and test anxiety. The }\end{array}$ \\
\hline $\begin{array}{l}\text { Accepted: } \\
17.08 .2020\end{array}$ & $\begin{array}{l}\text { research was conducted in two public high schools in Denizli } \\
\text { (Turkey) with } 729 \text { students. } 368 \text { participants }(50.5 \%) \text { were male } \\
\text { and } 361(49.5 \%) \text { were female. Motivated Strategies for Learning }\end{array}$ \\
\hline $\begin{array}{l}\text { Key words: } \\
\text { Geography c }\end{array}$ & Questionnaire (MSLQ) developed by Pintrich et al. and adapted to \\
\hline $\begin{array}{l}\text { Academic self-efficacy; } \\
\text { Test anxiety; } \\
\text { Task value }\end{array}$ & $\begin{array}{l}\text { Turkish by Karadeniz et al. was used as the data collection tool in } \\
\text { the study. Pearson correlation coefficients were calculated in order } \\
\text { to identify the relationship between variables. Additionally, } \\
\text { multiple regression analyses were conducted to determine the } \\
\text { regulating effect of self-sufficiency beliefs. The results indicated } \\
\text { the moderating effect of self-efficacy beliefs in the relationship } \\
\text { between task value and test anxiety. The higher self-efficacy } \\
\text { beliefs students had, the less test anxiety they perceived. Therefore, } \\
\text { students should be supported in a way that they can have complete, } \\
\text { successful, and the right kind of experiences which will allow them } \\
\text { to increase their perceptions of self-efficacy. The implications of } \\
\text { research are discussed in light of the literature and a number of } \\
\text { suggestions have been proposed accordingly. }\end{array}$ \\
\hline
\end{tabular}

\section{Introduction}

At present time, tests which are normally developed in order to measure students' academic success in courses are used for various reasons in many different areas. For example, authorities intensively utilize tests as tools to place students into high schools, in undergraduate, master's, and even in $\mathrm{PhD}$ programs. In this sense, tests are extremely important for students' career plans. In line with this, students exert efforts and do their best in order to achieve high scores in tests, and this process leads to intense stress and pressure on the part of the test taker viz. students. This situation is also referred to as test anxiety and it has become a global issue (Stankov, 2010).

\footnotetext{
*Correspondency: csanli@pau.edu.tr
} 
According to Nie, Lau, and Liau (2011) factors that result in test anxiety can be classified as those that decrease anxiety and those that increase anxiety. For instance, optimism is among the factors that decrease test anxiety. It has been observed that the higher an individual's optimism level is, the lesser their test anxiety becomes (Kleijn, Van der Ploeg, \& Topman, 1994). On the other hand, task difficulty is an example of factors increasing test anxiety. The higher an individual's perception of task difficulty, the more anxiety they experience (Eysenck, 1982). Studies focusing on identifying factors that are positively or negatively correlated with test anxiety are quite significant since such research provides important information with regards to strategies that can be used to decrease test anxiety. Such studies, on the other hand, do not explain how individual differences in belief systems affect the relationship between test anxiety and factors causing it. The present study investigated the regulating effect of academic self-efficacy beliefs in the relationship between test anxiety and task value which are among the factors that cause test anxiety. Determining such regulating effects is significant in that; studies exploring such regulating effects can provide useful information that can be used in developing practical applications to be used to decrease the negative effects of test anxiety in situations where it is impossible to eliminate factors triggering anxiety.

\section{Test Anxiety}

Test anxiety has been defined as an unpleasant mood which is experienced during a formal examination or evaluation setting; prevents individuals from delivering their real performance; has cognitive, emotional, and behavioural characteristics; and creates stress in the individual (Spielberger, 1995). Test anxiety has two dimensions; "worry" and "emotionality". "Worry" is the cognitive dimension of test anxiety. Negative evaluations that people make about themselves include their inner talks and ideas regarding their failure and inefficacy. The "worry" dimension involves processes through which individuals believe that they will not be able to provide what is necessary during the exam, not be able to solve a problem that they experience, or have ideas such as "what if I cannot do it; what if I cannot manage...". "Emotionality", on the other hand, is the emotional dimension where the autonomic nervous system, which forms the physiological part of test anxiety, is stimulated. Emotionality dimension is a process that involves physical reactions such as fast heart beats, sweating, fever, feeling cold, rash, nausea, bad temper, and stress (Spielberger \& Vogg, 1995). Analysis of the related literature indicates that test anxiety is generally measured using an aggregated score that consists of both dimensions of test anxiety (i.e. worry and emotionality) due to their high level of correlation (Bacanlı \& Sürücü, 2006; Birgin et al., 2010; Cameron \& Ferraro, 2004; Rodger, Murray \& Cummings, 2007). It has been reported that anxiety interacts with various variables (Lazarus \& Folkman, 1984; Spielberger \& Vagg, 1995; Zeidner, 2014), the relationship between self-beliefs (viz. self-sufficiency), cognitive factors relating to the task (i.e. task difficulty), and test anxiety has been studied by many researchers (Bonaccio \& Reeve, 2010; Çam,et.al., 2020; Devine, Fawcett, Szücs \& Dowker, 2012; Doğan, 2018; Morsanyi, Busdraghi \& Primi, 2014; Pintrich, Smith, Garcia \& McKeachie, 1993).

\section{Task Value and Test Anxiety}

Task value is a concept that relates to the extent to which individuals perceive the task to be useful and important. Task value has four elements which are; intrinsic value, utility value, attainment value, and cost (Eccles et al., 1983). Intrinsic value refers to the satisfaction and enjoyment that completing a task gives to people. Human beings are more eager and motivated to do a task that has intrinsic value for them. Therefore, they would be more determined to 
complete the task and exert more effort (Wigfield, Tonks \& Klauda, 2009). On the other hand, if a task provides an individual with opportunities to demonstrate and validate important parts of their personality then it has attainment value. Attainment value shows similarities with integrated regulation and identified regulation concepts that are part of the self-determination theory (Ryan \& Deci, 2009). To illustrate, a student who is interested in geography and is successful in geography classes start to perceive the geography course as an important part of their academic identity and they have the tendency to exert more effort when compared to other students. Another important component of value perception is cost. Cost refers to reasons that prevent an individual from completing a task or participating in an activity. The difficulty level of a task and the extent to which it requires effort are closely associated (Eccles \& Wigfield, 2002; Wigfield \& Eccles, 1992; Wigfield et al., 2009). When making decisions, people always take cost into consideration (Eccles et al., 1983). The chance that individuals would prefer easy tasks that do not require much effort is higher than normal tasks.

Researchers have claimed task-related beliefs to be among important factors that affect test anxiety (Wigfield \& Meece, 1988; Zeidner, 2014; Zeidner \& Matthews, 2005). In their mutual interaction model, Lazarus and Folkman (1984) claimed that the higher the task value was, the higher the test anxiety becomes. Covington (1985) tried to explain why task value caused test anxiety and stated that task value is perceived as a threat in circumstances where individuals have expectations of failure. The higher the value placed on the task, the higher the expectancy to become unsuccessful. Pekrun (1984), on the other hand, noted that anxiety is partially determined by the value system of an individual. The higher the value an individual place on a given task, the higher the probability of experiencing anxiety becomes.

Additionally, empirical research has supported theoretical explanations. For example, Wigfield and Meece (1988) found a moderate and positive relationship between task value and test anxiety among secondary and high school students. There are also studies which found a negative relationship between test anxiety and task value (i.e. Watson, 1988; Pajares \& Graham, 1999). One of the reasons for the inconsistency of the results in the literature can be related to the potential that this relationship might be regulated by various variables. In relation to this, the main aim of the present study is to reveal the effect of academic self-efficacy beliefs -a potential moderating variable- on the relationship between task value and test anxiety.

In general, task value is considered as a driving force that enables an individual to take action. If students consider a course to be important for them, they will have the tendency to put in more effort to become successful in that course. Research studies have corroborated that assumption (Durik et al., 2006; Lau \& Roeser, 2002; Wigfield \& Eccles, 1992; Wigfield et al., 2009). On the other hand, Nie, Lau, and Liau (2011) noted that task value can cause dilemmas in certain conditions. To cite an example, teachers and parents highlight the importance of courses so that the pupils can exert more effort. Whilst this can enable students to exert more effort, it can also cause students to experience higher levels of anxiety. Thereupon, highlighting the importance of academic tasks so as to decrease students' anxiety and worry is not a healthy approach to take. In fact, investigating the regulating effect of variables which can have an impact on the relationship between task value and test anxiety can provide valuable information with regards to appropriate measures that can be taken.

\section{Self-Efficacy Beliefs and Its Moderating Role}

Research studies revealed that test anxiety is affected by self-efficacy beliefs (Bonaccio \& Reeve, 2010; McMullan, Jones \& Lea, 2012; Morony et al., 2013; Onyeizugbo, 2010). Self- 
efficacy refers to an individual's beliefs regarding their skills to be able to successfully complete a given task (Bandura, 1997). According to Bandura, self-efficacy is a strong source that helps people protect themselves from psychological stressors. Someone whose self-efficacy beliefs are low can experience more anxiety than whose self-efficacy beliefs are high. This is because the given task is perceived as a threat when the individual's self-efficacy beliefs are low and as a challenge when the individual's self-efficacy beliefs are high. The increase in the importance of the task for the individual can result in the perception that the individual has a lot to lose when they do not complete the task successfully. People's self-efficacy beliefs reflect the extent to which they perceive themselves successful when given a task. In this sense, a given task becomes the source of intimidation and anxiety for those who believe that successfully completing the task is important for them, but who do not perceive that they have the capacity to complete the task (Nie, Lau \& Liau, 2011).

Self-efficacy theory suggests that self-efficacy is domain specific and represents the expectation of success in a particular task rather than a general belief about one's abilities (Bandura, 1997). Academic self-efficacy reflects students' beliefs regarding the extent to which they believe they will become successful in classroom activities (Midgley et al., 2000). Research has revealed a negative relationship between test anxiety and academic self-efficacy beliefs (Karadeniz et al., 2008; Meece et al., 1990; Nie, Lau \& Liau, 2011; Pintrich, Smith, Garcia \& McKeachie, 1993; Pintrich \& Degroot, 1990; Wigfield \& Meece, 1988). For example, Meece and colleagues (1990) underlined that there was a low and medium negative relationship between secondary and high school students' perceptions of their abilities and mathematics anxiety. Similarly, Nie, Lau, and Liau (2011) found a low and medium negative relationship between 9th grade students' academic self-efficacy beliefs and test anxiety in mathematics and English classes.

With that being said, there seems to be a limited number of research studies investigating the regulating effect of self-efficacy beliefs in the relationship between task value and test anxiety. Nie, Lau, and Liau (2011) investigated the regulating effect of academic self-efficacy in English and mathematics classes. They highlighted that academic self-efficacy beliefs weakened the relationship between task value and test anxiety. Nevertheless, the researchers concurred that there is a need to conduct further studies to be able to better understand the relationship among academic self-efficacy, task value, and test anxiety. In this sense, investigating the regulating effect of academic self-efficacy in other courses can be used to corroborate research findings. Geography course is one of the core courses that all students studying in high schools in Turkey should take (MoNE, 2018). In line with the above, the present study aimed to investigate the impact of 9th, 10th, 11th, and 12th grade high school students' academic self-efficacy beliefs in geography classes on the relationship between students' perceived task value and test anxiety.

Research hypotheses were developed in a way that could be tested utilizing regression analysis. The hypotheses included:

H1: when academic self-efficacy beliefs and the interaction variable is controlled, task value perceptions positively predict test anxiety,

$\mathrm{H} 2$ : when task value and the interaction variable is controlled, academic self-efficacy beliefs negatively affect test anxiety, and

H3: academic self-efficacy beliefs have a regulating effect in the relationship between task value and test anxiety. 


\section{Method}

\section{Participants}

The study was conducted with the participation of 729 high school students studying in two public high schools in Denizli province of Turkey. 368 of those students $(50.5 \%)$ were male and $361(49.5 \%)$ were female. 248 students (34 \%) studied in the 9th grade, $160(21.9 \%)$ in the 10th grade, $200(27.4 \%)$ in the 11th grade, and $121(16.6 \%)$ in the 12th grade. The mean age of participants was calculated as 15.58 years $(\mathrm{SD}=1.21)$.

\section{Procedure}

Initially, school administrators were contacted to arrange a suitable time for the administration of the questionnaire. Participation was on voluntary basis and students were informed about the study prior to data collection. On average, it took students five minutes to fill in the questionnaires in the classroom.

\section{Measures}

Motivated Strategies for Learning Questionnaire (MSLQ) developed by Pintrich, Smith, Garcia and McKeachie (1993) was utilized in the present study in order to identify high schools students' task value perceptions, test anxiety levels, and self-efficacy beliefs in geography classes. Karadeniz et al. (2008) adapted the Turkish version of the tool (MSLQ-TR). Two essential sections of the scale are the motivation and the learning strategies sections. The Motivation section has 6 factors and the learning strategies section has 9 factors, the subscales of MSLQ are modular and can be used on their own or together depending on a researcher's purpose (Karadeniz et al., 2008).

Motivation dimension includes intrinsic goal, extrinsic goals, task value, control of learning beliefs, academic self-efficacy, and test anxiety. The present study utilized only the task value, academic self-efficacy, and test anxiety factors. MSLQ-TR items are scored on a 7-point Likert scale ranging from 1 (not at all true of me) to 7 (very true of me). Task value, academic selfefficacy, and test anxiety can be subject-specific and change from one subject to another (Bandura, 1997). In this regard, the research tool was adapted into the geography course prior to administration.

\section{Academic Self-Efficacy}

Items within the academic self-efficacy factor measure students' confidence in learning geography topics and becoming successful in classroom activities. This factor included five items. The alpha reliability coefficient for those items was calculated as 0,69 (Karadeniz et al., 2008). The reliability coefficient in the present study was calculated as 0,90. Example items included: "I believe that I can understand even the most complex topics that the teacher would teach in geography classes", "Considering the difficulty of geography classes, the teacher, and my skills, I think I will be successful in this course". High scores achieved in this factor indicate that students have a high level of self-efficacy. 


\section{Task Value}

Items within the task value factor measure the extent to which students find geography topics to be interesting, useful, and important to learn. This factor included five items. The alpha reliability coefficient was calculated as 0,72 (Karadeniz et al., 2008). In the present study, the reliability coefficient was 0,85 . This factor includes statements such as: "I think I can transfer the information that I learn in geography classes into other classes" and "Learning geography topics is important for me". Achieving high scores in this factor suggests a high level of task value perception for a participant.

\section{Test Anxiety}

This factor indicates students' negative emotions regarding the geography course and students' concerns regarding their performance in geography classes. It aims to measure students' anxiety in geography classes and their emotional states. This factor included 5 items. Cronbach's alpha reliability coefficient in Karadeniz et al.'s (2008) study and in the present study were calculated as 0,66 and 0,85 respectively. "I think the answers I provide to exam questions in the geography course are worse than other students' answers" and "I think about the consequences of failure during geography exams" are among sample statements within this factor. Achieving high scores in this factor suggests the respondent has high exam anxiety.

The construct validity of this three-factor model (academic self-efficacy, task value, and test anxiety) was tested via Confirmatory Factor Analysis. The analysis was conducted using AMOS 24.0 software. The three-factor structure had a good model fit $\left(\chi^{2}(82, \mathrm{~N}=729)=397.15\right.$, TLI=0.92, CFI=0.94, RMSEA=0.07, SRMR=0.08, GFI=0.93, AGFI=0,90). CFI and TLI fit values ranged between 0 and 1 . CFI and TLI values between 0.90 and 0.95 suggest good model fit (McDonald and Marsh, 1990). Moreover, RMSEA and SRMR values lower than 0.08 also suggest acceptable model fit (Browne \& Cudeck, 1993). GFI and AGFI values above 90 indicate good model fit (Jöreskog ve Sörbom, 1993). Factor loadings following CFA ranged between 0,35 and 0,83 . All path coefficients in the model were significant at $p<0.001$.

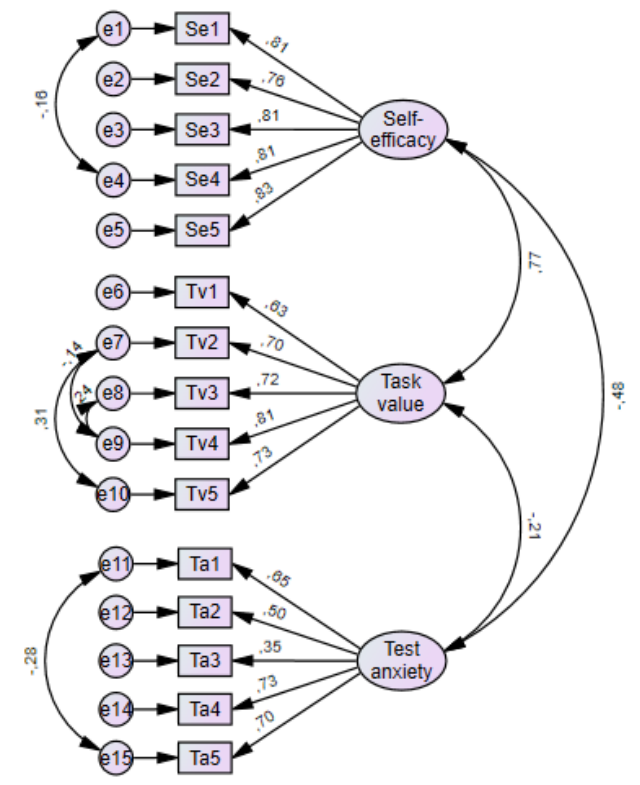

Figure 1. Confirmatory Factor Analysis Diagram $\left(\chi^{2}=397.15 ; \mathrm{Df}=82, p<0.001\right)$ 


\section{Data Analysis}

The univariate normality of distributions of the scores was assessed by calculating skewness and kurtosis values. For scores that are normally distributed, the skewness and kurtosis values should be zero, although values ranging between -1.0 and +1.0 may be considered to approximate a normal distribution (Tabachnick \& Fidell, 2007). Values for skewness in this study ranged between -0.43 and 0.08 , and for kurtosis between -0.62 and -0.48 indicating normality. Mardia's Kurtosis test was administered to check the normality of distribution. In this test coefficient values below 8 indicate that the dataset is normally distributed (Kline, 2011). The coefficient in the present study was calculated as 0,65 suggesting that the dataset was normally distributed.

Multicollinearity was tested by calculating the variance inflation factor (VIF), with values $>10$ indicating a problem (James, Witten, Hastie \& Tibshirani, 2013). The result showed no multicollinearity between variables $(1,06<\mathrm{VIF}<1,77)$. Durbin-Watson coefficient was calculated in order to test independent errors assumption. Coefficient values between 1,5 and 2,5 indicate that the data meets the assumptions of independent errors (Kalayc1, 2017) and the Durbin-Watson coefficient in this study was calculated as 2,04. The assumptions of homoscedasticity suggest different samples have the same variance. Visual examinations of the plot of standardized residuals (the errors) can be used to test this assumption (Osborne \& Waters, 2002). The analysis of the plots in this study showed that the residuals were generally distributed in the middle of the charts and in different regions. This indicated that there were no heterogeneous residuals. Additionally, scatter plots were checked to examine the linearity of the residuals. This analysis indicated that there was a linear relationship between the dependent and independent variables in this study. To summarize, the analyses suggested that the dataset met the assumptions required to conduct multivariate analyses.

Descriptive statistics were calculated to analyse the data collected from participants. Additionally, Pearson correlation coefficients were calculated to evaluate the relationships between factors. Finally, multiple linear regression analysis was administered to investigate the effects of task value, academic self-efficacy, and the relationship between task value and academic self-efficacy on test anxiety. All those analyses were conducted using SPSS 25.0 software.

\section{Results}

\section{Descriptive Statistics and Zero-Order Correlations}

The analysis of Table 1 shows a negative relationship between test anxiety and academic self-efficacy $(r=-0.35, p<0.01)$, and between test anxiety and task value $(r=-0.11, p<0.01)$. Nevertheless, interpretation of the correlation coefficients will be more accurate considering potential moderating relationships among the variables. In line with this, theory-driven regression analyses were conducted and main effects as well as moderating effects were investigated. 
Table 1. Descriptive statistics and zero-order correlations among variables

\begin{tabular}{lllllll}
\hline & Variable & Mean & SD & $\mathbf{1 .}$ & $\mathbf{2 .}$ & $\mathbf{3 .}$ \\
\hline 1. & Academic self-efficacy & 4.31 & 1.53 & 1 & & \\
2. & Task value & 4.51 & 1.43 & $0.65^{* *}$ & 1 & \\
3. & Test anxiety & 4.04 & 1.33 & $-0.35^{* *}$ & $-0.11^{* *}$ & 1 \\
${ }^{* *} \mathrm{p}<0.01$ & & & & &
\end{tabular}

\section{Regression Analysis}

Table 2. Regression Models Predicting Test Anxiety

\begin{tabular}{|c|c|c|c|}
\hline \multirow{2}{*}{ Predictors } & Model 1 & Model 2 & Model 3 \\
\hline & $\boldsymbol{\beta}$ & $\beta$ & $\beta$ \\
\hline Task value (TV) & $-0.11 * *$ & $0.21 * * *$ & $0.20 * * *$ \\
\hline Academic self-efficacy (AS) & & $-0.49 * * *$ & $-0.50 * * *$ \\
\hline TV X AS & & & $-0.10 * *$ \\
\hline$\Delta \mathrm{R}^{2}$ & 0.011 & 0.135 & 0.010 \\
\hline$\Delta \mathrm{F}$ & $8.45^{* *}$ & $115.08 * * *$ & $8.61 * *$ \\
\hline $\mathrm{R}^{2}$ & 0.011 & 0.147 & 0.157 \\
\hline Adjusted $\mathrm{R}^{2}$ & 0.010 & 0.144 & 0.153 \\
\hline $\mathrm{F}$ & $8.45^{* *}$ & $62.43 * * *$ & $44.93 * * *$ \\
\hline
\end{tabular}

$* * p<0.01, * * * p<0.001$

The analysis of Table 2 shows that task value perceptions negatively affect test anxiety (see Model $1, \beta=-0.11, p<0.01)$. As task value perceptions increase, test anxiety decreases. In the second model, academic self-efficacy was added into regression analysis as an independent variable. The second model suggested that when task value is controlled, academic self-efficacy negatively affects test anxiety $(\beta=-0.49, \mathrm{p}<0.001)$. In the third model, the interaction variable (TV X AS) was included in the regression analysis. In this model, when academic self-efficacy beliefs and interaction variables are controlled, task value perceptions positively impact test anxiety $(\beta=0.20, p<0.001)$. These results suggest that $\mathrm{H} 1$ hypothesis is valid. In this model, when task value and interaction variables are controlled, academic self-efficacy beliefs negatively influenced test anxiety $(\beta=-0.50, \mathrm{p}<0.001)$. These results suggest that $\mathrm{H} 2$ is valid.

With the addition of the interaction variable into the model the observed change in the $\mathrm{R}^{2}$ value was statistically significant $\left(\Delta \mathrm{R}^{2}=0.010, \Delta \mathrm{F}=8.61, \mathrm{p}<0.01\right)$. Furthermore, the effect of the interaction variable on test anxiety was found to be statistically significant $(\beta=-0.10, p<0.01)$. These results indicated that $\mathrm{H} 3$ hypothesis was also valid. Academic self-efficacy has a regulatory impact in the relationship between task value and test anxiety. Graphics were created and analyzed based on regression curves in order to better understand this regulatory impact (see Figure 2). The analysis of the graphic indicate that academic self-efficacy weakens the relationship between task value and test anxiety. As academic self-efficacy beliefs increase, the power of the relationship between task value and test anxiety decreases. 


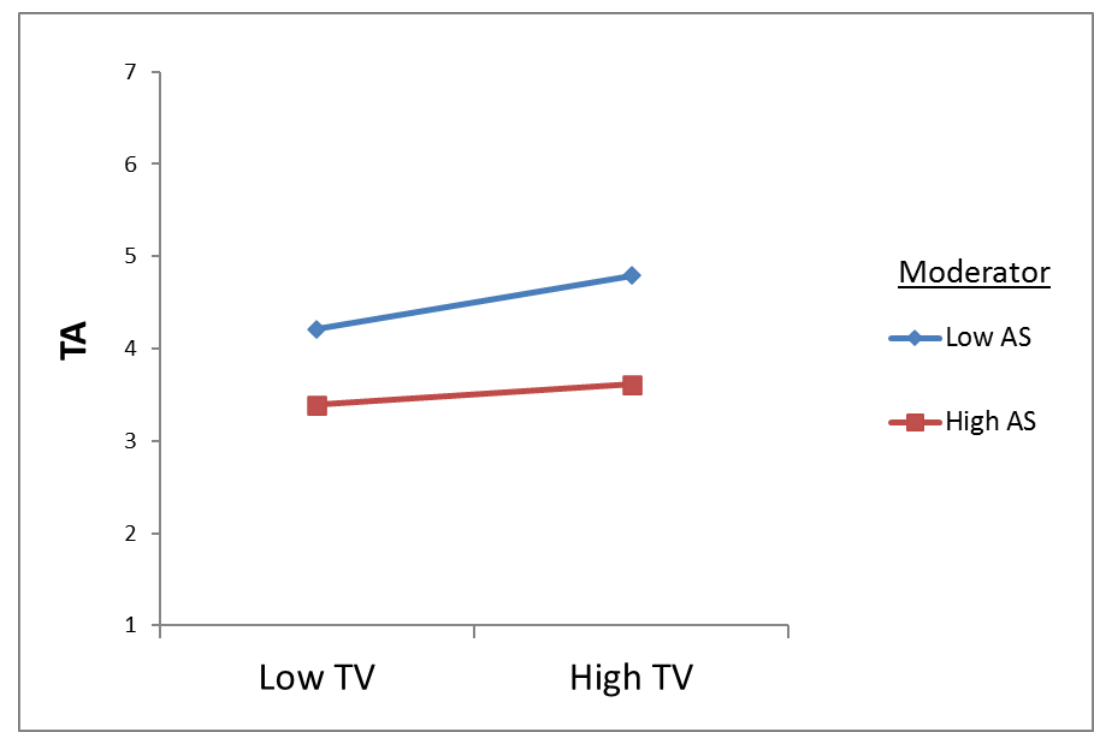

Figure 2. Plot of the interaction between task value and academic self-efficacy in predicting test anxiety, $\mathrm{TV}=$ Task value, $\mathrm{TA}=$ Test anxiety, $\mathrm{AS}=$ Academic self-efficacy.

\section{Discussion}

The main aim of the present study was to determine whether academic self-efficacy had a moderating effect on the relationship between task value and test anxiety. In line with this, the effects of task value, academic self-efficacy, and the interaction of these variables on test anxiety were revealed via multiple regression analysis.

\section{Task Value and Academic Self-Efficacy}

A positive and significant relationship was found between academic self-efficacy and task value. This result showed that self-efficacy and task value are constructs that are interrelated and not independent from each other. These results are in line with findings of other studies in the literature which investigated the relationship between similar variables. For example, Wigfield, Tonks, and Klauda (2009) found that the median of the relationship between American students' competence beliefs in various areas and their perceptions of task value was 0,23 among first graders, and 0,53 among sixth graders. Finding out a significant relationship between task value and academic self-efficacy showed that regression analysis can be administered to provide insights into more complex relationships between these variables. Multiple predictor variables were analyzed simultaneously thanks to regression analysis.

\section{Task Value as A Predictor of Test Anxiety}

Regression analysis results supported the research hypothesis (Hypothesis A) claiming that there is a positive relationship between task value and test anxiety when academic selfefficacy and interaction variables are controlled. This outcome indicates that zero-order correlation results which are calculated without taking academic self-efficacy into account can be misleading. This is because zero-order correlation analysis results revealed a negative relationship between task value and test anxiety. In a similar fashion, Nie, Lau, and Liau (2011) highlighted that test anxiety has a flexible structure and it is partially determined by individuals; value systems. The subjective value of perception of importance has been noted to be 
potentially related with whether being unsuccessful is perceived as a threat or loss. More specifically, when the importance of completing a task increases for people, being unsuccessful can be perceived as a threat or loss by them. Nie, Lau, and Liau (2011) pinpointed that there is a need to conduct further studies to better understand the relationships among task value, threat, loss, and unsuccessfulness. It has been found out that individuals with high perceptions of selfefficacy toward a task have higher tendencies to value a given task (Bandura, 1997). This explains the positive correlation found in the present research.

\section{Moderating Role of Academic Self-Efficacy}

Regression analysis results supported the research hypothesis (Hypothesis B) claiming that there is a negative relationship between academic self-efficacy and test anxiety when task value is controlled. This finding corroborates findings of related research in the literature (Meece, Wigfield \& Eccleset, 1990; Nie et al., 2011; Pintrich \& Degroot, 1990; Putwain \& Daniels, 2010). Additionally, another important finding in this study was that academic selfefficacy had a moderating effect in the relationship between task value and test anxiety which supported Research Hypothesis C. This finding is in line with Nie, Lau, and Liau's (2011) findings. Nie, Lau, and Liau (2011) noted that academic self-efficacy has a moderating effect on the relationship between task value and test anxiety in mathematics and English courses. They claimed that task value can cause individuals to think that they have a lot to lose when they are unable to complete a given task. Perceiving a given task to be important can cause individuals whose academic self-efficacy perceptions are low to consider the task as a threat and this can increase their anxiety levels. The higher academic self-efficacy perceptions individuals have, the weaker the positive relationship between task value and test anxiety becomes.

These results are also parallel to Lazarus and Folkman's (1984) explanations regarding transactional views of stress and anxiety. According to the mutual interaction model proposed by Lazarus and Folkman, people are not passive recipients of stimulators in their surroundings; instead, people select the stimulators they receive and they shape their surrounding accordingly. Cognitive processes and personal beliefs play an important role in whether people perceive a given task as a threat or obstacle. If they consider that they can control the result, the task would not be perceived as a threat or obstacle. In a similar vein, Bandura (1997) noted that selfefficacy beliefs play an important role in decision making processes and practicing their decisions in their lives. Students whose academic self-efficacy perceptions are high believe that they have sufficient cognitive resources necessary to learn their subjects and become successful in exams. Thus, they experience less test anxiety.

One of the implications of these results is that parents and teachers should take individual differences into account whilst trying to motivate their pupils following the method of highlighting the importance of a course. The results achieved in the present study also indicate that pinpointing the importance of task value (in this case importance of the geography course) might not always result in the desired outcomes. More specifically, underlining the importance of a task to students whose academic self-efficacy perceptions are low can increase perceptions of threat resulting in students experiencing threat. 


\section{Limitations and Recommendations}

Like in any research, the present study also has a number of limitations. For example, the research studied psychological constructs such as academic self-efficacy through self-report measures. Future research can utilize different data collection tools when investigating this topic. On a different note, the study is based on correlational research. Thereupon, causal inferences should be avoided. Repeating this research following an experimental research approach can provide insights into the causal relationships among the studied variables. The cross-sectional research design followed in the present study allows researchers to understand complex relationships only at a given time. In line with this, longitudinal studies can be planned to track down students' beliefs towards geography classes. Such longitudinal studies can contribute to a better understanding of students' beliefs towards geography classes. The present study utilized MSLQ to measure psychological constructs. Future studies can utilize different tools to measure such constructs.

\section{Conclusions}

Task value is generally considered as an important source of motivation that enables student learning. On the other hand, the present study revealed that low levels of academic selfefficacy perceptions can result in increases in students' anxiety levels. This suggests that approaches which underline task value to decrease students' test anxiety do not provide appropriate solutions. Instead, it is considered that approaches which strengthen students' selfefficacy perceptions are more feasible to decrease their test anxiety. Bandura (1997) stated that there are four main sources of self-efficacy beliefs; personal experiences, indirect experiences, verbal persuasion, and physiological state. Personal experiences, in particular, are the strongest predictor of self-efficacy beliefs. In this sense, students should be assisted so that they can have the kind of experiences necessary to increase their self-efficacy perceptions. Last but not the least, these results indicate the importance of moderating variable analysis to better comprehend the relationships among variables affecting students' motivational beliefs.

\section{References}

Bacanlı, F., \& Sürücü, A. G. M. (2006). An examination of the relationship between test anxiety and decision making styles of elementary school 8th grades students, Educational Administration: Theory and Practice, 45(45), 7-35.

Bandura, A. (1997). Self-efficacy: The exercise of control. New York: W.H. Freeman.

Birgin, O., Baloglu, M., Çatlıglu, H., \& Gürbüz, R. (2010). An investigation of mathematics anxiety among sixth through eighth grade students in Turkey. Learning and Individual Differences, 20(6), 654-658.

Bonaccio, S., \& Reeve, C. L. (2010). The nature and relative importance of students' perceptions of the sources of test anxiety. Learning and Individual Differences, 20(6), 617-625.

Browne, M. W., \& Cudeck, R. (1992). Alternative ways of assessing model fit. Sociological methods \& research, 21(2), 230-258.

Cameron, E. M., \& Ferraro, F. R. (2004). Body satisfaction in college women after brief exposure to magazine images. Perceptual and Motor Skills, 98(3), 1093-1099.

Covington, M. V. (1985). Test anxiety: Causes and effects over time. Advances in test anxiety research, 4, 55-68. 
Çam, Z., Ekşısu, M., Kardaş, F., Saatçıoğlu, Ö., Gelibolu, S. (2020). The mediating role of selfefficacy in the relationship between problem solving and hope, Participatory Educational Research (PER),7(1), 47-58.

Devine, A., Fawcett, K., Szücs, D., \& Dowker, A. (2012). Gender differences in mathematics anxiety and the relation to mathematics performance while controlling for test anxiety. Behavioral and Brain Functions, 8(1), 1-9.

Doğan, İ. (2018). Examination of the technology leadership self-efficacy perceptions of educational managers in terms of the self-efficacy perceptions of information technologies (Malatya province case). Participatory Educational Research (PER), 5(2), 51-66.

Durik, A. M., Vida, M., \& Eccles, J. S. (2006). Task values and ability beliefs as predictors of high school literacy choices: A developmental analysis. Journal of Educational Psychology, 98(2), 382-393.

Eccles (Parsons), J. S., Adler, T. F., Futterman, R., Goff, S. B., Kaczala, C. M., Meece, J. L., \& Midgley, C. (1983). Expectancies, values, and academic behaviors. In J. T. Spence (Ed.), Achievement and achievement motivation (pp. 75-146). San Francisco, CA: W. H. Freeman.

Eccles, J. S., \& Wigfield, A. (2002). Motivational beliefs, values, and goals. Annual Review of Psychology, 53(1), 109-132.

Eysenck, M. W. (1982). Attention and arousal: Cognition and performance. Berlin: SpringerVerlag.

James, G., Witten, D., Hastie, T., \& Tibshirani, R. (2013). An introduction to statistical learning (vol. 112). New York: Springer.

Jöreskog, K. G., ve Sörbom, D. (1993). LISREL 8: Structural equation modeling with the simplis command language. Lincolnwood: Scientific Software International, Inc.

Kalayc1, Ş. (2017). SPSS uygulamalı çok değişkenli istatistik teknikleri ( 8th Edition) [Multivariate statistical techniques with SPSS application ] Ankara: Asil Publication.

Karadeniz, S., Buyukozturk, S., Akgun, O. E., Cakmak, E. K., \& Demirel, F. (2008). The Turkish adaptation study of motivated strategies for learning questionnaire (MSLQ) for 12-18year old children: results of confirmatory factor analysis. Turkish Online Journal of Educational Technology, 7(4), 1-10.

Kleijn, W. C., van der Ploeg, H. M., \& Topman, R. M. (1994). Cognition, study habits, test anxiety, and academic performance. Psychological Reports, 75(3), 1219-1226.

Kline, R. B. (2011). Convergence of structural equation modeling and multilevel modeling. In M. Williams, \& W. P. Vogt (Eds.), Handbook of methodological innovation (pp. 562589) Thousand Oaks, CA: Sage.

Lau, S., \& Roeser, R. W. (2002). Cognitive abilities and motivational processes in high school students' situational engagement and achievement in science. Educational Assessment, 8, 139-162.

Lazarus, R. S., \& Folkman, S. (1984). Stress, appraisal, and coping. New York, NY: Free Press.

McDonald, R. P., \& Marsh, H. W. (1990). Choosing a multivariate model: Noncentrality and goodness of fit. Psychological bulletin, 107(2), 247-255.

McMullan, M., Jones, R., \& Lea, S. (2012). Math anxiety, self-efficacy, and ability in British undergraduate nursing students. Research in Nursing \& Health, 35(2), 178-186.

MoNE (Ministry of National Education) (2018). Geography course curriculum (Secondary school 9, 10, 11 and 12th grades). http://mufredat.meb.gov.tr/Dosyalar/2018120203724482Cografya\%20dop\%20pdf.pdf, Accessed January 10, 2019. 
Meece, J. L., Wigfield, A., \& Eccles, J. S. (1990). Predictors of math anxiety and its influence on young adolescents course enrollment intentions and performance in mathematics. Journal of Educational Psychology, 82(1), 60-70.

Midgley, C., Maehr, M. L., Hruda, L. Z., Anderman, E., Anderman, L., Freeman, K. E., et al. (2000). Manual for the patterns of adaptive learning scales. Ann Arbor, MI: University of Michigan.

Morony, S., Kleitman, S., Lee, Y. P., \& Stankov, L. (2013). Predicting achievement: Confidence vs self-efficacy, anxiety, and self-concept in Confucian and European countries. International Journal of Educational Research, 58, 79-96.

Morsanyi, K., Busdraghi, C., \& Primi, C. (2014). Mathematical anxiety is linked to reduced cognitive reflection: a potential road from discomfort in the mathematics classroom to susceptibility to biases. Behavioral and Brain Functions, 10, (1), 31, https://behavioralandbrainfunctions.biomedcentral.com/articles/10.1186/1744-908110-31, Accessed March 7, 2019.

Nie, Y., Lau, S., \& Liau, A. K. (2011). Role of academic self-efficacy in moderating the relation between task importance and test anxiety. Learning and Individual Differences, 21(6), 736-741.

Onyeizugbo, E. U. (2010). Self-efficacy and test anxiety as correlates of academic performance. Educational Research, 1(10), 477-480.

Osborne, J., \& Waters, E. (2002). Four assumptions of multiple regression that researchers should always test. Practical assessment, research \& evaluation, 8(2), 1-9.

Pajares, F., \& Graham, L. (1999). Self-efficacy, motivation constructs, and mathematics performance of entering middle school students. Contemporary Educational Psychology, 24(2), 124-139.

Pekrun, R. (1984). An expectancy-value model of anxiety. In H. M. Van der Ploeg, R. Schwarzer, \& C. D. Spielverger (Eds.), Advances in test anxiety research, (vol. 3. pp. 53-72) Lisse, The Netherlands: Swets \& Zeitlinger.

Pintrich, P. R., \& Degroot, E. V. (1990). Motivational and self-regulated learning components of classroom academic-performance. Journal of Educational Psychology, 82(1), 33-40.

Pintrich, P. R., Smith, D. A., Garcia, T., \& McKeachie, W. J. (1993). Reliability and predictive validity of the Motivated Strategies for Learning Questionnaire (MSLQ). Educational and Psychological Measurement, 53(3), 801-813.

Putwain, D. W., \& Daniels, R. A. (2010). Is the relationship between competence beliefs and test anxiety influenced by goal orientation? Learning and Individual Differences, 20(1), 8-13.

Rodger, S., Murray, H. G., \& Cummings, A. L. (2007). Effects of teacher clarity and student anxiety on student outcomes. Teaching in Higher Education, 12(1), 91-104.

Ryan, R. M., \& Deci, E. L. (2009). Promoting self-determined school engagement: Motivation, learning, and well-being. In: K. R. Wentzel \& A. Wigfield (Eds), Handbook of motivation in school. New York: Taylor Francis.

Spielberger, C. D. (1995). Preliminary manual for the State-Trait Personality Inventory (STPI). Tampa, FL: Center for Research in Behavioral Medicine and Health Psychology, University of South Florida.

Spielberger, C. D., \& Vagg, P. R. (1995). Test anxiety: A transactional process model. In C. D. Spielberger \& P. R. Vagg (Eds.), Series in clinical and community psychology. Test anxiety: Theory, assessment, and treatment (p. 3-14). Taylor \& Francis.

Stankov, L. (2010). Unforgiving Confucian culture: A breeding ground for high academic achievement, test anxiety and self-doubt? Learning and Individual Differences, 20(6), 555-563. 
Tabachnick, B. G., \& Fidell, L. S. (2007). Using multivariate statistics. Boston, MA: Allyn \& Bacon/Pearson Education.

Watson, J. M. (1988). Achievement anxiety test dimensionality and utility. Journal of Educational Psychology, 80(4), 585-591.

Wigfield, A., \& Eccles, J. S. (1992). The development of achievement task values: A theoretical analysis. Developmental Review, 12(3), 265-310.

Wigfield, A., \& Meece, J. L. (1988). Math anxiety in elementary and secondary-school students. Journal of Educational Psychology, 80(2), 210-216.

Wigfield, A., Tonks, S., \& Klauda, S. L. (2009). Expectancy-value theory. In K. R. Wentzel \& A. Wigfield (Eds.), Handbook of motivation at school (pp. 55-76). Routledge: New York.

Zeidner, M. (2014). Anxiety in education. in R. Pekrun \& L. Linnenbrink-Garcia (Eds.), International handbook of emotions in education (pp. 265-288). New York, NY: Taylor \& Francis.

Zeidner, M., \& Matthews, G. (2005). Evaluation anxiety: Current theory and research. In A. J. Elliot, \& C. S. Dweck (Eds.), Handbook of competence and motivation (pp. 141-163). New York: Guilford. 